\title{
POCZUCIE KOHERENCJI W KONSTRUOWANIU KARIERY (KONTEKST CAŁOŻYCIOWEGO ROZWOJU JEDNOSTKI) ${ }^{1}$
}

\begin{abstract}
AвSTRACT. Piorunek Magdalena, Poczucie koherencji w konstruowaniu kariery (kontekst całożyciowego rozwoju jednostki) [The Sense of Coherence in Career Structuring (a Context of Lifelong Development of an Individual)]. Studia Edukacyjne nr 40, 2016, Poznań 2016, pp. 21-38. Adam Mickiewicz University Press. ISSN 1233-6688. DOI: 10.14746/se.2016.40.2
\end{abstract}

The text The Sense of Coherence in Career Structuring (a Context of Lifelong Development of an Individual) describes the salutogenetic concepts of health and sense of coherence by A. Antonovsky that serve as an inspiration for reflections about the structuring of an individual's vocational career. The Sense of Coherence $(S O C)$ is a global orientation that expresses the extent to which one has an enduring and dynamic feeling of confidence that: - stimuli coming throughout one's lifetime from the internal and external environments are structured, predictable and explainable (the sense of comprehensibility a cognitive component); - resources are at one's disposal which are adequate to meet the demands posed by these stimuli (the sense of manageability - a cognitive-instrumental component); - these demands are challenges that are worth investing effort and engagement (the sense of meaningfulness - an emotional-motivational component); The essay presents a hypothesis that the Sense of Coherence, as it develops over one's lifetime, may foster an effective structuring (planning and realisation) of one's vocational career. A bi-directional relation exists between the structuring of one's high and stable sense of coherence and the development of the biographical thinking and shaping of one's biographical competence. These competencies can be developed in the process of upbringing and education and fostered by vocational guidance, especially in its non-directive dimension (coaching, tutoring).

Key words: sense of coherence, sense of comprehensibility, sense of manageability and meaningfulness, vocational career, biographical thinking, biographical competence, career guidance

1 Prezentowany tekst powstał na kanwie referatu, zatytułowanego: Poczucie koherencji w konstruowaniu kariery. Perspektywa całożyciowego zrównoważonego rozwoju jednostki, wygłoszonego przez autorkę na Międzynarodowej Konferencji Naukowej organizowanej przez Katedrę UNESCO Całożyciowego Poradnictwa Zawodowego oraz European Society for Vocational Designing and Career Counseling - „Konstruowanie kariery i life design na rzecz zrównoważonego rozwoju i godnej pracy" (Career and Life Design interventions for sustainable development and decent work) 6-8 czerwca 2016 roku we Wrocławiu. 


\section{Salutogenetyczna koncepcja zdrowia i poczucia koherencji Antonovsky'ego jako inspiracja do rozważań o pracy i karierze}

Niniejsze rozważania zostały zainspirowane tezami pochodzącymi z psychologii i socjologii zdrowia ${ }^{2}$, które zaimplementowano do rozważań dotyczących całożyciowego rozwoju jednostki w kontekście konstruowania przez nią kariery zawodowej. Przyjęto bowiem założenie, że zrównoważone funkcjonowanie człowieka wiąże się z jego zdrowiem. Przy czym, nie traktowano konstruktu zdrowia w sposób tradycyjny, zgodny z koncepcją biomedyczną czy patogenetyczną, w której jest ono po prostu brakiem choroby.

Odwołano się tu do współczesnych modeli zdrowia, mianowicie do modelu holistycznego, salutogenetycznego oraz charakterystycznego dla psychologii pozytywnej. W rozważaniach tych musimy po pierwsze przyjąć, że zdrowie ma kilka wymiarów (aspektów), w tym fizyczny, psychiczny (emocjonalny i umysłowy), społeczny oraz duchowy.

Warunkiem zdrowia społecznego, rzutującego na pozostałe jego wymiary, jest zdolność do nawiązywania, podtrzymywania i rozwijania prawidłowych relacji z innymi ludźmi, która wiąże się z niezakłóconym funkcjonowaniem w zróżnicowanych środowiskach życia. W przypadku osób dorosłych (na różnych etapach dorosłości - wczesnej, średniej, późnej) jednym z wymiarów funkcjonowania społecznego jest wymiar zawodowy i środowisko pracy wpływające na globalną ocenę dobrostanu jednostki.

W salutogenetycznej koncepcji zdrowia Aarona Antonovsky'ego jednostka w cyklu całożyciowego rozwoju znajduje się na kontinuum rozpiętym pomiędzy zdrowiem a chorobą. Zdrowie traktowane jest jako wartość, którą się osiąga, buduje w toku życia. „Orientacja salutogenetyczna skłania do myślenia $\mathrm{w}$ kategoriach czynników sprzyjających przesuwaniu się na kontinuum w kierunku zdrowia"3. Podejście patogenetyczne ogniskowało się na chorobie i jej zapobieganiu, a w konsekwencji sprowadzało do poszukiwania remedium na określone choroby. $\mathrm{W}$ orientacji salutogenetycznej

2 Por. np. G. Dolińska-Zygmunt (red.), Podstawy psychologii zdrowia, Wrocław 2001; H. Sęk, T. Pasikowski (red.), Zdrowie - stres - zasoby, Poznań 2001; H. Sęk, R. Cieślak (red.), Wsparcie społeczne, stres i zdrowie, Warszawa 2004; T. Pasikowski, H. Sęk (red.), Psychologia zdrowia. Teoria, metodologia, empiria, Poznań 2006; I. Heszen, H. Sęk, Psychologia zdrowia, Warszawa 2007; I. Heszen, J. Życińska (red.), Psychologia zdrowia. W poszukiwaniu pozytywnych inspiracji, Warszawa 2008; A. Ostrowska (red.), Socjologia medycyny. Podejmowane problemy, kategorie analizy, Warszawa 2009; B. Woynarowska, Edukacja zdrowotna, Warszawa 2016.

3 A. Antonovsky, Rozwikłanie tajemnicy zdrowia. Jak radzić sobie ze stresem i nie zachorować, Warszawa 1995, s. 23 (wydanie z 2005 roku - Instytut Psychiatrii i Neurologii, Warszawa). 
zdrowie i choroba to wymiary jakości życia, a pozbycie się choroby nie jest jedynym i zasadniczym celem działań, ale zależy nam na umożliwieniu człowiekowi dobrego życia, osiągnięciu dobrostanu. W salutogenezie poszukujemy skutecznych dróg przystosowania społecznego, co zmusza badacza czy klinicystę do zrozumienia we współpracy z jednostką historii życia człowieka (nie tylko pacjenta), który w jego przebiegu zmaga się ze stresem.

W koncepcji salutogenetycznej poziom zdrowia warunkują trzy zasadnicze czynniki:

- stresory,

- uogólnione zasoby odpornościowe oraz

- poczucie koherencji.

Stresory definiuje autor jako bodźce, dla których nie ma gotowych, zautomatyzowanych reakcji adaptacyjnych4; rodzą one stan napięcia, wprowadzają entropię, sprzeczność, inicjują zmianę. Mogą to być zarówno bodźce o zabarwieniu negatywnym, jak i pozytywnym, czy ambiwalentnym. Przy czym, Antonovsky zwraca uwagę na mobilizacyjną funkcję stresu w sytuacji gdy człowiek poradzi sobie ze stanem napięcia, tj. kontroluje emocje i podejmuje działania instrumentalne. Stresor nie zawsze ma charakter niepożądany, eustres (tzw. stres pozytywny) wręcz pobudza do działania, sprzyja aktywności i uzyskiwaniu zadowolenia. Stresory mogą zatem pełnić funkcję rozwojową, sprzyjać poznawaniu świata, nabywaniu nowych umiejętności w sytuacji kiedy człowiek dysponuje zasobami wystarczającymi do redukcji stanu napięcia.

Uogólnione zasoby odpornościowe (Generalised Resistance Resources) pozwalają jednostce skutecznie radzić sobie ze stresem. Lindstrom ${ }^{5}$ klasyfikuje wspomniane zasoby na czterech poziomach: indywidualnym, interpersonalnym, zewnętrznym i krajowym (globalnym). Poziom indywidualny odnosi się do zasobów biologicznych, psychologicznych, osobowościowych jednostki. Zasoby interpersonalne dotyczą relacji międzyludzkich budujących kapitał społeczny. Zasoby zewnętrzne odnoszą się zaś do sfery ekonomii, edukacji, kultury. Poziom globalny z kolei charakteryzowany jest przez makro i socjokulturowe cechy społeczeństwa, które determinują ustrój polityczny i kapitał kulturowy (np. religijny, filozoficzny, historyczny).

Poczucie koherencji (Sense of Coherence), czyli globalna orientacja człowieka, wyraża stopień, w jakim człowiek ten ma dojmujące, trwałe, choć dynamiczne poczucie pewności, że:

4 Tamże.

${ }^{5}$ M. Piotrowicz, D. Cianciara, Teoria salutogenezy - nowe podejście do zdrowia i choroby, Przegląd Epidemiologiczny, 2011, 65, s. 521-527. 
1) bodźce napływające w ciągu życia ze środowiska wewnętrznego i zewnętrznego mają charakter ustrukturowany, przewidywalny i wytłumaczalny (poczucie zrozumiałości; comprehensibility - komponent poznawczy); dzięki tej właściwości człowiek potrafi zorientować się poznawczo w otoczeniu, które aktualnie na niego oddziałuje, jest zdolny do opisu otoczenia we wszystkich jego uwarunkowaniach ${ }^{6}$. Człowiek o silnym poczuciu zrozumiałości oczekuje, że zdarzenia, które pojawią się w przyszłości, będą przewidywalne, a jeśli nieoczekiwanie pojawi się jakiś bodziec, będzie mógł go do czegoś przyporządkować7;

2) dostępne są zasoby, które pozwolą mu sprostać wymaganiom stawianym przez te bodźce (poczucie zaradności - sterowalności; manageability komponent poznawczo-instrumentalny); to przekonanie, że człowiekowi dostępne są (lub będzie ich aktywnie poszukiwał) zasoby, za pomocą których poradzi sobie $\mathrm{w}$ sytuacji tego wymagającej;

3) wymagania te są dla niego wyzwaniem wartym wysiłku i zaangażowania (poczucie sensowności; meaningfulness - komponent emocjonalnomotywacyjny)" 8 . Wiąże się on z poczuciem wartości doświadczeń życiowych i przekonaniem, że warto się angażować i kreować swoją biografię, starając się sprostać wymaganiom i radzić z wyzwaniami.

Poczucie koherencji jest orientacją dyspozycyjną (nie zaś cechą osobowościową) - stosunkowo stabilną, choć rozwijającą się przez całe życie, tendencją do postrzegania świata jako zrozumiałego, sensownego i poddającego się działaniom podmiotu oraz jako takiego, w którym przeważać będą elementy pozytywne nad negatywnymi ${ }^{9}$.

Komponenty poczucia koherencji są zasadniczo nierozdzielne i wzajemnie od siebie zależne, a pozycja na kontinuum koherencji utrwala się na etapie wczesnej dorosłości, około 30 . roku życia ${ }^{10}$. Jednostka realizująca zadania rozwojowe tego okresu jest już w znacznym stopniu związana $\mathrm{z}$ określonymi osobami, środowiskami, w tym środowiskami zawodowymi, rolami, zakresami zadań. Poziom poczucia koherencji nie ulega najczęściej w ciągu dalszego życia zasadniczym zmianom, chociaż mogą na niego wpływać doraźnie np. nagłe, trudne, krytyczne wydarzenia życiowe. Omawiana kon-

${ }^{6}$ H. Sęk, I. Ścigała, Stres i radzenie sobie w modelu salutogenetycznym, [w:] Człowiek w sytuacji stresu. Problemy teoretyczne i metodologiczne, red. I. Herszen-Niejodek, Z. Ratajczak, Katowice 1996.

\footnotetext{
7 A. Antonovsky, Rozwikłanie tajemnicy zdrowia.

8 Tamże, s. 34.

${ }^{9}$ Tamże.

10 Tamże.
} 
cepcja wskazuje tylko na niewielkie fluktuacje wokół względnie stałego miejsca na kontinuum poczucia koherencji.

Zagadnienie stabilności vs. zmienności poczucia koherencji było niejednokrotnie poddawane analizie $w$ badaniach longitudinalnych, ale ich wyniki nie pozwalały na sformułowanie jednoznacznych wniosków.

Na rozwój poczucia koherencji wpływają, wspomniane wcześniej, zgeneralizowane zasoby odpornościowe oraz doświadczenia nabywane $\mathrm{w}$ biegu życia jednostki. Kształtuje się ono dzięki powtarzającemu się wzorowi doświadczeń życiowych, który charakteryzuje się trzema własnościami:

- spójnością,

- równowagą w zakresie przeciążenia - niedociążenia oraz

- udziałem $w$ podejmowaniu decyzji ${ }^{11}$.

Spójność doświadczeń oznacza pewną ich powtarzalność i możliwość uporządkowania $\mathrm{w}$ trzech wymiarach temporalnych - przeszłości, teraźniejszości i przyszłości. Zadanie to wydaje się szczególnie trudne $\mathrm{w}$ dobie ponowoczesnego chaosu, płynności rzeczywistości społecznej, czy funkcjonowania w społeczeństwie ryzyka, w których funkcję zewnętrznych dystraktorów pełni wielość nieskoordynowanych bodźców kulturowych, podlegających dodatkowo wielokierunkowym, permanentnym zmianom ${ }^{12}$.

Równowaga między przeciążeniem a niedociążeniem powstaje wówczas, kiedy wyzwania, którym w biegu życia musimy sprostać, są adekwatne do możliwości wiekowych i psychofizycznych jednostki. Niedociążenie może prowadzić do frustracji i poczucia bezsensu, przeciążenie wyczerpuje zasoby jednostki. Wydaje się jednak, że stan lekkiego przeciążenia ma raczej charakter prorozwojowy, jeżeli pozostaje $\mathrm{w}$ związku z poczuciem zaradności (mam wiele wyzwań, zadań do zrealizowania, ale jestem w stanie z tym się uporać...).

Udział w podejmowaniu decyzji przyczynia się z kolei do kształtowania poczucia sensowności. Oznacza on choćby minimalny udział w kreowaniu (nie kontrolowaniu, bowiem większość zdarzeń nie jest i nie może być cał-

11 Por. np. J. Koniarek, B. Dudek, Z. Makowska, Kwestionariusz Orientacji Życiowej. Adaptacja The Sense of Coherence Questionnaire (SOC) A. Antonovsky'ego, Przegląd Psychologiczny, 1993, 36; I. Werner, Poczucie koherencji a praca, [w:] Człowiek w kontekście pracy. Teoria - Empiria Praktyka, red. M. Piorunek, Torun 2009; A. Worsztynowicz, Coaching a poczucie koherencji, Forum Oświatowe, 2013, 2(49).

12 Por. Z. Bauman, Ptynna nowoczesność, Kraków 2006; tegoż, Płynne czasy. Życie w epoce niepewności, Warszawa 2007; tegoż, Płynne życie, Kraków 2007; U. Beck, Społeczeństwo ryzyka. $W$ drodze do innej nowoczesności, Warszawa 2002; A. Giddens, Nowoczesność i tożsamość. "Ja" i społeczeństwo w epoce późnej nowoczesności, Warszawa 2007. 
kowicie kontrolowanych przez jednostkę) rzeczywistości; wyrażanie zgody na realizację i ponoszenie odpowiedzialności za wywiązywanie się z zadań jest niezbędne $w$ kształtowaniu poczucia uczestnictwa, zaangażowania, czy autonomii ${ }^{13}$. Wydaje się, że $\mathrm{w}$ korporacyjnych środowiskach pracy, w których udział szeregowych pracowników $\mathrm{w}$ podejmowaniu decyzji jest ograniczony do minimum, nie stwarza się warunków sprzyjających podnoszeniu poczucia sensowności wykonywanej pracy.

\section{Badacze zakładają, że}

im silniejsze poczucie koherencji, tym większe prawdopodobieństwo postrzegania różnorodnych bodźców, sytuacji, raczej jako wyzwania, z którymi można sobie poradzić, w które warto inwestować energię niż jako paraliżującego zagrożenia czy niebezpieczeństwa. Osoby z silnym poczuciem koherencji w konfrontacji z potencjalnie szkodliwą sytuacją będą bardziej, niż te o niskim poziomie koherencji, skłonne do określenia jej jako takiej, której nie muszą ulegaćn ${ }^{4}$.

W sytuacjach nierozwiązywalnych osoby $\mathrm{z}$ wysokim poczuciem koherencji radzą sobie lepiej zarówno w kategoriach adaptacyjnych, jak i emocjonalnego stosunku do sytuacji (mniejsze cierpienie) ${ }^{15}$.

Badania empiryczne potwierdzają, że osoby o silnym poczuciu koherencji skuteczniej radząc sobie ze stresem, jednocześnie mają większe możliwości zachowania zdrowia ${ }^{16}$. Wpływ poczucia koherencji na uogólniony stan zdrowia uwidacznia się $\mathrm{w}$ wielu płaszczyznach funkcjonowania człowieka: od sprawności układu immunologicznego po uogólnioną aktywność społeczną. Wewnętrzne przekonanie jednostki o koherencji świata zewnętrznego - jego zrozumiałości, sensowności i dostępności zasobów umożliwiających intencjonalne nań oddziaływania - sprzyja konstruktywnemu radzeniu sobie ze zróżnicowanymi sytuacjami życiowymi i angażowaniu się $\mathrm{w}$ aktywność prozdrowotną ${ }^{17}$.

Antonovsky stworzył narzędzie do badania poczucia koherencji - Kwestionariusz Orientacji Życiowej (SOC-29), które jest powszechnie wykorzystywane $\mathrm{w}$ badaniach społecznych. Wydaje się, że można także badać tę

\footnotetext{
${ }^{13}$ A. Antonovsky, Rozwikłanie tajemnicy zdrowia.

14 Por. np. J. Koniarek, B. Dudek, Z. Makowska, Kwestionariusz Orientacji Życiowej, s. 494495.

${ }^{15}$ A. Antonovsky, Rozwikłanie tajemnicy zdrowia.

16 Por. np.: H. Sęk, Salutogeneza i funkcjonalne właściwości poczucia koherencji, [w:] Zdrowie stres - zasoby, red. H. Sęk, T. Pasikowski, Poznań 2001; I. Heszen, H. Sęk, Psychologia zdrowia, Warszawa 2007.

17 A. Antonovsky, Rozwikłanie tajemnicy zdrowia.
} 
orientację wykorzystując paradygmat interpretatywny oraz jakościowe badania narracyjne.

\section{Rozwój poczucia koherencji w biegu życia człowieka}

Poczucie koherencji kształtuje się na podstawie doświadczeń życiowych jednostki.

(...) Spójność doświadczeń jest czynnikiem warunkującym kształtowanie się poczucia zrozumiałości; właściwa równowaga niedociążenia i przeciążenia - poczucia zaradności; współudział w decydowaniu o wyniku (nie chodzi o wymiar kontroli, tylko podejmowania decyzji [przyp. M.P.] - poczucia sensowności (... $)^{18}$.

Świat, w którym jesteśmy sprowadzeni do roli przedmiotu, w którym nikt nie liczy się z naszym zdaniem, wydaje się jednostce bezsensowny, niezależnie od tego, jakiego wymiaru funkcjonowania taka ocena dotyczy. Co nie oznacza $\mathrm{w}$ praktyce, że takie doświadczenia, $\mathrm{w}$ których nie podejmujemy decyzji na nas nie oddziałują.

Ten „wzorzec doświadczeń życiowych” 19 kształtujący się w cyklu całego życia, uwarunkowany i różnicowany kulturowo, wpływa na budowanie i utrwalanie poczucia koherencji.

Przyjrzyjmy się zatem syntetycznie jednej z najbardziej rozpowszechnionych, uznanych koncepcji rozwoju człowieka w cyklu życia, wskazując warunki dla rozwoju poczucia koherencji (do tej koncepcji nawiązywał także Antonovsky).

W neopsychoanalitycznej koncepcji E. Eriksona ${ }^{20}$ odwołującego się do koncepcji Freuda, autor podkreśla ciągłość procesu rozwoju osobowospołecznego. Dokonuje się on poprzez kryzysy wyrażające napięcie pomiędzy aktualnymi możliwościami jednostki a społecznymi wymaganiami, jakie stawia przed nią otoczenie.

Na niezwykle dynamiczny, transformatywny etap dzieciństwa, który obejmuje tzw. wczesne dzieciństwo (etap niemowlęcy i poniemowlęcy od 0-3 roku życia), średnie dzieciństwo (ok. 3-5 lat) oraz późne stadium tego etapu (ok. 6-11 lat) przypadają aż cztery kryzysy normatywne.

18 Tamże, s. 94.

19 Tamże, s. 95.

${ }^{20}$ E.H. Erikson, Identity Youth and Crisis, New York 1968; tegoż, Identitaet und Lebenszyklus, Frankfurt am Mein 1989; tegoż, Dzieciństwo i społeczeństwo, Poznań 1997; E.H. Erikson, J.M. Erikson, Dopetniony cykl życia, Gliwice 2012. 
0-1 rok życia - ufność vs. nieufność. Na tym etapie istotna jest konsekwencja, ciągłość i troska służąca zaspokajaniu potrzeb dziecka, które rodzą przekonanie, że świat jest bezpieczny i godny zaufania.

Z czasem niemowlę lub dziecko nabiera przekonania, że może liczyć na to, że świat fizyczny i społeczny, w którym przyszło mu żyć, nie będzie się bezustannie zmieniał. Rozmaite bodźce napływające $z$ wnętrza organizmu i ze świata zewnętrznego oraz reakcje na te bodźce spostrzegane są jako znane i powtarzalne. W takim przypadku wstępny obraz świata staje się dla dziecka zrozumiały21.

Niemowlę zaczyna mieć udział w podejmowaniu decyzji na tyle, na ile od niego zaczyna zależeć osiąganie celów, na ile jego zachowania i reakcje mobilizują otoczenie do działania, a jednocześnie tej mobilizacji towarzyszą pozytywne emocje (przekaz: jesteś kimś ważnym dla nas) - świat zaczyna dla niego nabierać sensowności. Z czasem rozwijające się dziecko uczy się zaradności $\mathrm{w}$ interakcjach $\mathrm{z}$ otoczeniem, doświadczając konsekwencji swoich działań i reakcji, odbierając wzmocnienia pozytywne i negatywne.

2-3 rok życia - autonomia vs. zwatpienie. Na tym etapie dziecko intensywnie eksploruje rzeczywistość, a zachęcanie go do aktywności, prób działania we własnym tempie i na własny sposób prowadzi do ukształtowania u niego poczucia autonomii. W przeciwnym wypadku, zbyt częste, nieadekwatne karcenie, krytykowanie, czy wyręczanie dziecka sprzyja jego zwątpieniu we własne możliwości. Wspomniana autonomia w działaniu przyczynia się do kształtowania poczucia zaradności w sytuacjach społecznych.

3-5 rok życia - inicjatywa czy poczucie winy. Poszerzanie zakresu swobody $\mathrm{w}$ podejmowaniu działań, uważne odnoszenie się do pytań dziecka sprzyja przejawianiu inicjatywy. Zbyt daleko idące sztywne zakazy, przy okazywaniu zniecierpliwienia i permanentnym wytwarzaniu poczucia naprzykrzania się przez dziecko, buduje $\mathrm{w}$ nim poczucie winy względem przejawów własnej aktywności. Odbiera zatem dziecku szansę na kształtowanie poczucia zrozumiałości, sensowności świata i poczucia zaradności w stosunku do jego wyzwań.

6-11 rok życia - pracowitość vs. poczucie niższości. Dziecko na skutek poszerzających się kręgów oddziaływań socjalizacyjnych, w tym kontaktów z instytucjami - wcześniej przedszkole, potem szkoła - ma szansę znacznie poszerzać także swoje doświadczenia społeczne i uzupełniać je o doświadczenia nauki, która w przeciwieństwie do aktywności zabawowej służy realizacji zadań podlegających weryfikacji i ocenie. Dziecko chętnie wykonuje wiele czynności, coś wytwarza, angażuje się w wiele aktywności, co w sytu-

${ }^{21}$ A. Antonovsky, Rozwikłanie tajemnicy zdrowia, s. 97. 
acji gdy zostaje dostrzeżone i docenione kształtuje poczucie pracowitości. Nadmierna krytyka czy bagatelizowanie jego wysiłków rodzi w nim poczucie niższości, które jednocześnie obniża jego poczucie zaradności.

Kolejnym, newralgicznym etapem rozwojowym staje się adolescencja (etap dorastania), stanowiąca swoisty pasaż pomiędzy dzieciństwem a dorosłością.

Kryzys tego okresu koncentruje się wokół tożsamości vs. niejasności (dyfuzji) roli. Głównym problemem, przed którym stają młodzi ludzie na tym etapie, jest zintegrowanie swojego zachowania i znalezienie odpowiedzi na pytanie: kim jestem i kim chcę być w przyszłości? Jeśli adolescent odnajduje ciągłość i stałość swoich zachowań i osobowości w oczach innych, w zróżnicowanych kontekstach społecznych rodzi się w nim poczucie tożsamości wie kim jest. Antonovsky odnosi owo poszukiwanie siebie do wymiarów poczucia koherencji, wskazując, że młody człowiek musi zrozumieć świat, nauczyć się radzić sobie w rolach (poczucie zaradności) i znaleźć sens otaczającego świata poprzez uprawomocnienie swojej w nim obecności (poczucie sensowności). Adolescencja w specyficzny sposób wiąże cykl życia rodzinnego i edukacyjno-zawodowego ${ }^{22}$. Ważną barierę rozwojową tego okresu stanowi niezdolność do obrania tożsamości zawodowej, gdyż ta jest rozstrzygająca $\mathrm{w}$ kwestii punktualnego wejścia w krąg odpowiedzialności charakterystycznych dla dorosłości. Na ten etap wewnętrznego kryzysu tożsamości młodego człowieka nakłada się zewnętrznie sterowany system edukacyjny ze swoją rozrządową funkcją, uwidaczniającą się zwłaszcza na progach pomiędzy poszczególnymi etapami szkolnictwa. To w okresie adolescencji ujawnia się orientacja życiowa, powstają projekty kariery, dokonywane są cząstkowe wybory edukacyjne i zawodowe. Jednostka na progu dorosłości, gromadząc dotychczasowe doświadczenia społeczne oparte na bazowych wartościach i celach wytyczanych w cyklu życia (a w jego ramach - w toku kariery zawodowej), postrzega swą przyszłość w określonych kategoriach deskryptywnych i ewaluatywnych. Może budować określone wizje swych przyszłych ról rodzinnych i zawodowych. Plany życiowe stanowią formę refleksyjnie zorganizowanej trajektorii tożsamości. Planowanie życia to sposób wprowadzania do realizacji przez jednostkę przebiegu przyszłych

22 Por. stadia rozwoju zawodowego Supera, np.: D.E. Super, The psychology of careers, New York 1957; tegoż, A life- span, life-space approach to career development, [w:] Career choice and development: Applying contemporary theories to practice, red. W.D. Brown, L. Brooks, San Francisco 1990; S.H. Osipow, Theories of carrer development, New Jersy 1973; R. Smart, C. Peterson, Super's career stages and the decision to change careers, Journal of Vocational Behavior, 1997, 51, s. 358374. 
działań w kontekście ciągłości personalnej biografii ${ }^{23}$. Zdaniem Eriksona, $\mathrm{w}$ okresie dorastania mamy jeszcze do czynienia $\mathrm{z}$ rodzajem moratorium psychospołecznego, stanowiącego zaprogramowane opóźnienie zarówno rozwoju osobowości, jak i statusu społecznego, gwarantującego przejściowość i pozostawiającego przestrzeń dla eksperymentowania z różnymi rolami społecznymi bądź za pomocą regresywnych powtórzeń, bądź skokowych antycypacji odbywających się na skrajnie różnych obszarach, których wewnętrzne sprzeczności nie są postrzegane. Moratorium jest instytucjonalną formą usankcjonowania okresu oczekiwania przyznanego młodemu człowiekowi zanim podejmie obowiązki i odpowiedzialność osoby dorosłej. Kontekst kulturowy (miejsce wzrastania, czas historyczny, typy kultur: otwarte z szerokim wachlarzem opcji wyborów życiowych, homogeniczne i zamknięte, destrukcyjne, uniemożliwiające odkrycie sensu życia) i rzeczywistość społeczno-strukturalna sprzyjają vs. przeszkadzają w zdobywaniu życiowych doświadczeń, które w różnym stopniu dadzą młodemu człowiekowi poczucie zrozumienia, sensu otaczającego świata oraz zaradności w zmaganiu się z życiowymi przeciwnościami i stresem dnia codziennego.

Dorosłość obejmująca wczesny wiek dojrzały (20/23 - 30/35 rok życia), średni (35/40 - 55/60 rok życia) i późną dorosłość (powyżej 55/60) 24 utrwala lub zmienia nabyte we wcześniejszych fazach rozwojowych poczucie koherencji. Przy czym, według Antonovsky'ego zasadnicze znaczenie dla ukształtowania poczucia koherencji na określonym poziomie mają przede wszystkim doświadczenia pierwszych trzech dekad życia człowieka.

(...) Wejście w wiek dorosły, a co za tym idzie, związanie się na dłużej z określonymi osobami, rolami społecznymi, pracą, utrwala lub odwraca doświadczenia nabyte $\mathrm{w}$ dzieciństwie i okresie dorastania, na dobre lub złe $(\ldots)^{25}$.

Pierwsze poważne doświadczenia związane z pracą przypadają na okres nazywany w ponowoczesności „wyłaniającą się dorosłością" (emerging adulthood ${ }^{26}$, obejmujący $\mathrm{w}$ przybliżeniu $18-25$ rok życia. Ten etap rozwojowy charakteryzuje się jeszcze brakiem skrystalizowanej tożsamości, otwartością na zmiany, akceptacją statusu tymczasowości, gotowością do eksperymentowania w życiu, przeplataniem nauki z pracą. Doświadczenia tego okresu, ale i całej wczesnej dorosłości, mogą być ważnym przyczynkiem do formo-

${ }^{23}$ A. Giddens, Nowoczesność i tożsamość.

24 B. Harwas-Napierała, Możliwości wspomagania rozwoju jednostki na różnych etapach okresu dorostości, [w:] Pomoc - wsparcie społeczne - poradnictwo. Od teorii do praktyki, red. M. Piorunek, Toruń 2010.

${ }^{25}$ A. Antonovsky, Rozwikłanie tajemnicy zdrowia, s. 106.

${ }^{26} \mathrm{~J} . J$. Arnett, Emerging adulthood. A theory of development from the late teens through the twenties, American Psychologist, 2000, 55(5), s. 469-480 pdf 
wania pewnych zgeneralizowanych orientacji życiowych, w tym także poczucia koherencji. Pełniejszy i bardziej stabilny związek z pracą i pełnionymi $\mathrm{w}$ niej rolami utrwala się w kolejnych latach życia, kiedy zasadniczo poziom poczucia koherencji jest już ukształtowany.

Wczesny wiek dojrzały zogniskowany jest wokół normatywnego Eriksonowskiego kryzysu intymność vs. odosobnienie. Erikson podkreśla zasadnicze zadanie tego okresu, jakim jest dokonanie wyboru partnera i ustalenie pozycji zawodowej (rozwijanej $\mathrm{w}$ dalszych etapach biografii), które prowadzi jednostkę do intymnych związków z innymi ludźmi lub w przypadku niepowodzenia - do poczucia izolacji od życia i społeczeństwa.

Antonovsky analizuje związki pomiędzy różnymi czynnikami środowiska pracy a poszczególnymi komponentami poczucia koherencji. Warunkiem poczucia sensowności danej pracy zawodowej jest poczucie uczestnictwa $\mathrm{w}$ podejmowaniu decyzji. Można je osiągnąć poprzez doświadczanie zadowolenia, dumy z wykonywanej pracy i/lub doświadczanie poczucia swobody wyboru. $\mathrm{W}$ tym pierwszym przypadku istotne jest przeświadczenie jednostki o wartości społecznej, istotności, wadze danej aktywności zawodowej oraz poczucie własnej wartości jako pracownika. Wzmocnieniem takich stanów rzeczy staje się docenianie i sprawiedliwa ocena wykonywanej pracy. W drugim zaś przypadku, odnoszącym się do swobody wyboru, możemy wskazywać na możliwość podejmowania decyzji co do sposobu wykonywania zawodowych zadań (wybór tempa, metod pracy, kolejności wykonywanych czynności itd.), możliwości współdecydowania w sytuacjach wymagających współpracy z ludźmi lub/i możliwości wywierania wpływu na całokształt wykonywanej pracy.

Warunkiem umacniania poczucia zaradności w środowisku pracy jest doświadczanie odpowiedniej równowagi obciążeń (good load-balance) ${ }^{27}$. Praca w warunkach niedociążenia nie stwarza możliwości wykorzystania potencjału pracownika, nie daje mu możliwości wpływania na rzeczywistość. $\mathrm{Z}$ kolei, obciążenia nadmierne, w toku których człowiek jest stale/często konfrontowany $\mathrm{z}$ warunkami przekraczającymi dostępne mu zasoby, a jednocześnie nie ma możliwości czasowego zawieszenia aktywności i regeneracji sił, powodują spadek poczucia zaradności (przeświadczenie: nie daje już rady...).

Poczucie zrozumiałości będzie kształtowane w warunkach pracy odbieranych przez jednostkę jako względnie przewidywalne, ustrukturalizowane, czemu sprzyja wysoki poziom pewności zatrudnienia, zdefiniowanie miejsca, roli i zadań poszczególnych pracowników w systemie organizacyjnym.

27 A. Antonovsky, Rozwiktanie tajemnicy zdrowia. 
(...) Poczucie zrozumiałości będzie silniejsze, gdy relacjom społecznym w miejscu pracy towarzyszy wspólnota wartości, norm, symboli i języka, czyli innymi słowy, gdy kultura organizacyjna będzie wyraźnie wyodrębniona ${ }^{28}$.

Należy podkreślić, że związek poczucia koherencji i pracy ma charakter dwukierunkowy, to znaczy, że poziom poczucia koherencji jest kształtowany poprzez doświadczenia płynące z pracy, ale jednocześnie jest ono jednym $\mathrm{z}$ istotnych faktorów wpływających na funkcjonowanie w pracy (radzenie sobie ze stresem, podejmowanie wyzwań, zmaganie z nimi), będące elementem dobrostanu psychicznego i determinantą zdrowia ${ }^{29}$.

(...) Ten ostatni aspekt ogniskujący się w podstawowej hipotezie koncepcji SOC mówiącej o tym, że im silniejsze poczucie koherencji, tym korzystniejsze umiejscowienie jednostki na kontinuum zdrowie - choroba, znalazł swoje empiryczne potwierdzenie. I tak na przykład, wykazano, że silny SOC negatywnie koreluje z postrzeganiem stresu w pracy (np. Albertsen i wsp., 2001; Kalimo i wsp., 2002), dużymi wymaganiami środowiska pracy (np. Holmberg, 2004), doświadczaniem przemocy w pracy (Hogh, Mikkelsen, 2005), emocjonalnym wyczerpaniem w pracy (np. Feldt i wsp., 1997) i wypaleniem zawodowym (np. Baker i wsp., 1997; Kalimo i wsp., 2003). Natomiast pozytywny związek SOC $\mathrm{w}$ kontekście środowiska pracy zademonstrowano między innymi w odniesieniu do: przystosowania zawodowego (Strauser, Lustig, 2003), poczucia sprawowania kontroli (Holmberg i wsp., 2004), satysfakcji życiowej (Kalimo, Vuori, 1991), dobrostanu psychicznego (np. Kalimo i wsp., 2002) i zdrowia fizycznego (np. Poppius i wsp., 1999) (...) $)^{30}$.

Z kolei Strauser i Lustig31 pozytywnie zweryfikowali hipotezę o pomyślnym związku poczucia koherencji z poziomem przystosowania zawodowego. Potwierdzili

(...) istnienie pozytywnego, chociaż umiarkowanego związku pomiędzy poczuciem koherencji a osobowością pracowniczą i kompetencjami pracowniczymi. W szczególności, wszystkie pięć czynników operacjonalizujących osobowość pracowniczą oraz kompetencje pracownicze (tj. zdolność do prezentowania swoich możliwości poznawczych, zdolność do nawiązywania kontaktów społecznych, zdolność do akceptowania zastanych procedur i otwartość na zmiany, zdolności adaptacyjne związane $\mathrm{z}$ wymaganiami roli oraz zdolność do stosownego odnoszenia się do autorytetów) pozytywnie korelowało z wynikami SOC $(. . .)^{32}$.

\footnotetext{
${ }^{28}$ I. Werner, Poczucie koherencji a praca, s. 115.

${ }^{29}$ A. Antonovsky, Rozwikłanie tajemnicy zdrowia.

${ }^{30}$ I. Werner, Poczucie koherencji a praca, s. 116.

${ }^{31}$ D.R. Strauser, D.C. Lustig, The moderating effect of sense of coherence on work adjustment, Journal of Employment Counseling, 2003, 40, s. 129-140.

32 I. Werner, Poczucie koherencji a praca, s. 118.
} 
Należy przypuszczać, że poczucie koherencji wprawdzie zasadniczo ukształtowane $w$ pierwszych trzech dekadach życia, mogące ulegać jednak modyfikacjom pod wpływem kolejnych doświadczeń życiowych ${ }^{33}$, przyczynia się (warunkuje, pośredniczy, jest efektem) do dalszego zaangażowania biograficznego, w tym zawodowego, a więc konstruowania i realizowania kolejnych etapów kariery zawodowej na etapie średniej dorosłości.

Na tym etapie kryzys (w koncepcji Eriksona) zasadza się na poczuciu produktywności vs. zaabsorbowania sobą. Średnia dorosłość wiąże się zatem z zapewnieniem możliwości rozwoju następnego pokolenia, które dokonuje się poprzez przekaz generacyjny $\mathrm{w}$ rodzinie (wychowywanie dzieci, wnuków) czy w środowisku pracy (przekazywanie doświadczeń młodszym współpracownikom, kierowanie, organizowanie pracy innych osób) lub szerszym środowisku lokalnym. Niezdolność do takich działań skłania do koncentracji na sobie. Można zaryzykować hipotezę, wymagającą wszak weryfikacji empirycznej, że osoby mające poczucie sensu swoich doświadczeń życiowych i zawodowych, umiejące je uspójnić, co przyczynia się do ukształtowania poczucia zrozumiałości, dobrze radzące sobie z życiowymi wyzwaniami (poczucie zaradności), chętniej i skuteczniej będą angażować się $\mathrm{w}$ działania sprzyjające bezpośredniemu i/lub symbolicznemu przekazywaniu wiedzy, umiejętności, doświadczenia kolejnym pokoleniom, choćby na niwie zawodowej.

Późna dorosłość sprzyja z kolei budowaniu poczucia integralności vs. rozpaczy. Coraz częstsze zwracanie się ku przeszłości, w sytuacji gdy prowadzi ono do akceptacji życia takim, jakie było, rodzi poczucie integralności, sprzyja zrozumieniu, nadaniu sensu całej trajektorii biograficznej i budowaniu pozytywnego bilansu życiowego związanego z poczuciem zaradności (dobrze poradziłem sobie $w \dot{z} y c i u . .$.$) . W przeciwnym wypadku do głosu do-$ chodzą emocje negatywne, rozpacz, poczucie życiowej porażki i beznadziei.

\section{Poczucie koherencji jako orientacja dyspozycyjna w procesie konstruowania kariery zawodowej}

Kariera ma charakter temporalny i procesualny, odnoszący się do przebiegu zindywidualizowanego doświadczenia jednostki, konstruowanego w obiektywnych realiach społeczno-kulturowych, zogniskowanych wokół przejawów aktywności człowieka na rynku pracy. Ma charakter dualistycz-

33 A. Antonovsky, Rozwikłanie tajemnicy zdrowia. 
ny, bowiem odnosi się zarówno do obiektywno-historycznego wymiaru funkcjonowania na rynku pracy (sekwencja zawodowych zadań, obowiązków, stanowisk, relacji pracowniczych), jak i do aspektów subiektywnoprzeżyciowych funkcjonowania jednostki (indywidualna interpretacja doświadczeń w świecie pracy naznaczona przez system wartości, oczekiwania, aspiracje, potrzeby i emocje jednostki). Kariera łączy w sobie trzy perspektywy temporalne (przeszłość z teraźniejszością i przyszłością).

Jej konstruowanie przez jednostkę obejmuje następujące procesy i zjawiska:

- Działania o charakterze preparacyjnym, tj. planowanie, projektowanie drogi edukacyjno-zawodowej i podejmowanie decyzji (mniej lub bardziej uszczegółowionych) odnośnie do poszczególnych aspektów biegu życia zawodowego.

(...) Planowanie życia zakłada specyficzny sposób organizacji czasu, ponieważ refleksyjna konstrukcja własnej tożsamości wymaga tyleż przygotowania się na przyszłość, co interpretacji przeszłości, chociaż na pewno istotną rolę w tym procesie odgrywa zawsze "przerabianie" przeszłych zdarzeń $(\ldots)^{34}$. Planowanie życia jest szczególnym przypadkiem „kolonizacji przyszłości” (... $)^{35}$.

- Aktywność o charakterze realizacyjnym, tj. wdrażanie poszczególnych elementów planu lub jego modyfikowanie bądź spontaniczne odpowiadanie na impulsy otoczenia (przypadek w karierze).

W świetle zaproponowanych wcześniej rozważań dotyczących salutogenetycznej koncepcji zdrowia Antonovsky'ego można zaryzykować hipotezę, że stabilne wysokie poczucie koherencji, tj. poczucie zrozumiałości obejmujące ustrukturyzowanie, spójność i przewidywalność doświadczeń zawodowych oraz poczucie zaradności warunkowane przeświadczeniem o posiadaniu i/lub możliwości efektywnego poszukiwania zasobów ułatwiających zmaganie się z trudnościami zawodowymi oraz przeświadczenie o sensowności świata społeczno-zawodowego, uzyskiwane $\mathrm{w}$ toku zaangażowania i uczestnictwa $\mathrm{w}$ podejmowaniu decyzji zawodowych, sprzyja efektywnemu konstruowaniu kariery w cyklu życia człowieka. Mam tu na myśli przede wszystkim subiektywno-przeżyciowy aspekt kariery, nie podlegający zewnętrznym ewaluacjom; idzie zatem o samopoczucie jednostki, nie zaś (lub $\mathrm{w}$ mniejszym stopniu) o obiektywne miejsce $\mathrm{w}$ hierarchii społecznej wyznaczone przez zatrudnienie. Jeśli zatem jednostka ma poczucie, że rozumie świat swojego zawodowego funkcjonowania (role przypisane i kreowane,

\footnotetext{
34 A. Giddens, Nowoczesność i tożsamość, s. 119.

35 Tamże, s. 121.
} 
zakresy zadań i zależności itd.), radzi sobie z jego wyzwaniami na kontinuum niedociążenie - przeciążenie oraz wymagania te są dla niej wyzwaniem wartym wysiłku i zaangażowania (zaangażowanie zawodowe jest przez jednostkę odbierane na poziomie emocjonalno-motywacyjnym jako sensowne) dobrze radzi sobie z planowaniem i realizowaniem kariery zawodowej. Z drugiej zaś strony przewidywalne, ustrukturyzowane środowisko pracy, stwarzające możliwości świadomego współuczestniczenia w decyzjach pracowniczych, dające szansę na uzyskiwanie wsparcia w realizacji pojawiających się trudności i problemów zawodowych, sprzyja budowaniu poczucia koherencji jednostki.

Naturalnie, sformułowana powyżej hipoteza wymagałaby weryfikacji empirycznych, które stałyby się możliwe dopiero po operacjonalizacji poszczególnych jej komponentów - zmiennych oraz opracowaniu ich wskaźników.

Nie sposób oprzeć się jednak pokusie kontynuowania tej hipotetycznej refleksji, a przede wszystkim przełożeniu jej na język działań wspierających budowanie owego wysokiego poczucia koherencji.

Wydaje się, że istnieją co najmniej dwie drogi służące temu celowi. Jedną z nich, o charakterze uniwersalnym, jest wychowanie i edukacja, drugą zaś o charakterze spersonalizowanym - poradnictwo kariery, zwłaszcza w jego niedyrektywnym wymiarze, stawiającym jednostce cele profilaktycznooptymalizacyjne $\mathrm{w}$ odniesieniu do przebiegu życia i kariery. Szczególne możliwości stwarza w tym względzie coaching (w różnych odmianach: życiowej, karierowej, indywidualnej, grupowej) i/lub tutoring, realizowany w odniesieniu do różnych pól aktywności człowieka.

Wspólnym mianownikiem wszystkich tych działań (jakiekolwiek byśmy zastosowali etykiety danej formy wsparcia) jest dążenie do refleksyjnego spojrzenia przez jednostkę na całość lub fragmenty swojej życiowej/ karierowej drogi i uzyskiwanie przez nią samoświadomości w zakresie jej biograficznych zasobów umożliwiających rozumienie świata, poruszanie się $\mathrm{w}$ nim (zmaganie $\mathrm{z}$ trudnościami, reagowanie na stresory) i traktowanie poszczególnych wymiarów tej aktywności personalnej jako sensownych, wartych tego zaangażowania.

(...) Przedmiotem myślenia biograficznego jest droga życiowa podmiotu oraz jego rozwój, a w zależności od orientacji temporalnej przybiera ono postać refleksji nad przeszłością, oceny aktualnej sytuacji życiowej, projektowania bądź prognozowania przyszłości. Można scharakteryzować je również jako dążenie do rozpatrywania znaczących problemów życiowych nie doraźnie - lecz w łączności z historią i przyszłością $(\ldots)$. 
Przeżywanie „siebie w czasie” wymaga wyjścia poza koncentrację na aktualnym wymiarze doświadczeń, bowiem przeszłość zawsze jakoś „żyje” w jednostce, wyznaczając jej utrwalone sposoby reagowania, wzorce myślenia i działania, wpływając też na preferowane przez nią wartości i postawy. Jej aktualny świat przeżyć i aktywność życiowa wyznaczane są również przez to, czego oczekuje ona w bliższej i dalszej przyszłości. Jednocześnie nie pozostaje ona w swej aktualnej sytuacji „zawieszona w próżni” - żyje bowiem w obrębie świata wartości, które selekcjonują oraz ukierunkowują jej przeżycia i działania. Wgląd jednostki $\mathrm{w}$ to, co dla niej ważne stanowi jeden $\mathrm{z}$ istotnych elementów myślenia biograficznego. Jego kolejny składnik stanowi umiejętność określenia życiowego celu oraz - choćby intuicyjnie uchwycenia idei łączącej poszczególne wydarzenia w znaczące całości.

Poszukiwanie nadrzędnego celu oraz „idei wiodącej” (...) jest wyrazem dążenia do poznawczego uporządkowania ogromu posiadanych informacji, a jednocześnie do odkrycia ich znaczenia i sensu $(. . .)^{36}$.

Myśleniu temu sprzyja rozwijanie

(...) kompetencji biograficznej definiowanej jako zdolność nie tylko do całościowego i perspektywicznego ujmowania własnego życia wraz z określaniem własnego miejsca na drodze rozwoju, ale również - poparta realnymi działaniami - gotowość do decyzyjnego i behawioralnego intencjonalnego współtworzenia własnej biografii. Rozwinięta kompetencja biograficzna przejawia się w mądrości życiowej oraz umiejętności kierowania własnym życiem, wyrażających się $\mathrm{w}$ takim sposobie spożytkowania wydarzeń i doświadczeń, którego efektem staje się w konsekwencji uznanie biegu własnego życia za udany $(. . .)^{37}$.

Używając zatem języka teorii Antonovsky'ego, myślenie biograficzne sprzyja zrozumieniu siebie, otoczenia i relacji jednostka - otoczenie, zaangażowaniu się w te relacje (poczucie zaradności) oraz nadaniu im sensu, sprzyja zatem budowaniu poczucia koherencji, będąc jednocześnie przez tę dyspozycję warunkowane.

Kształtowanie myślenia biograficznego i kompetencji biograficznych staje się z jednej strony elementem narracyjnej promocji zdrowia i poradnictwa egzystencjalnego ${ }^{38}$, z drugiej zaś służy refleksyjnemu konstruowaniu kariery zawodowej, stanowiącej płaszczyznę zrównoważonego funkcjonowania społecznego jednostki.

36 U. Tokarska, Kształcenie kompetencji biograficznej jako forma profilaktyki problemów egzystencjalnych wspótczesnego człowieka, [w:] Poradnictwo. Kolejne przybliżenia, red. M. Piorunek, Toruń 2011, s. 67.

${ }^{37}$ Tamże, s. 68.

38 Tamże. 


\section{BIBLIOGRAFIA}

Antonovsky A., Rozwikłanie tajemnicy zdrowia. Jak radzić sobie ze stresem i nie zachorować, Fundacja IPN, Warszawa 1995.

Arnett J.J., Emerging adulthood. A theory of development from the late teens through the twenties, American Psychologist, 2000, 55(5), pdf.

Bauman Z., Płynna nowoczesność, Wydawnictwo Literackie, Kraków 2006.

Bauman Z., Płynne życie, Wydawnictwo Literackie, Kraków 2007.

Bauman Z., Ptynne czasy. Życie w epoce niepewności, Wydawnictwo Sic!, Warszawa 2007.

Beck U., Społeczeństwo ryzyka. W drodze do innej nowoczesności, Wydawnictwo Naukowe Scholar, Warszawa 2002.

Dolińska-Zygmunt G. (red), Podstawy psychologii zdrowia, Wydawnictwo Uniwersytetu Wrocławskiego, Wrocław 2001.

Erikson E.H., Identity Youth and Crisis, W.W. Norton\&Company, New York 1968.

Erikson E.H., Identitaet und Lebenszyklus, Shurkamp Taschenbuch Verlag, Frankfurt am Mein 1989.

Erikson E.H., Dzieciństwo i społeczeństwo, Dom Wydawniczy Rebis, Poznań 1997.

Erikson E.H., Erikson J.M., Dopetniony cykl życia, Helion, Gliwice 2012.

Giddens A., Nowoczesność i tożsamość. "Ja" i społeczeństwo w epoce późnej nowoczesności, Wydawnictwo Naukowe PWN, Warszawa 2007.

Harwas-Napierała B., Możliwości wspomagania rozwoju jednostki na różnych etapach okresu dorostości, [w:] Pomoc - wsparcie społeczne - poradnictwo. Od teorii do praktyki, red. M. Piorunek, Wydawnictwo Adam Marszałek, Torun 2010.

Heszen I., Sęk H., Psychologia zdrowia, Wydawnictwo Naukowe PWN, Warszawa 2007.

Heszen I., Życińska J. (red), Psychologia zdrowia. W poszukiwaniu pozytywnych inspiracji, Wydawnictwo SWPS „Academica”, Warszawa 2008.

Koniarek J., Dudek B., Makowska Z., Kwestionariusz Orientacji Życiowej. Adaptacja The Sense of Coherence Questionnaire (SOC) A. Antonovsky'ego, Przegląd Psychologiczny, 1993, 36.

Osipow S.H., Theories of career development, Prentice-Hall, Englewood C., New Yersey 1973.

Ostrowska A. (red), Socjologia medycyny. Podejmowane problemy, kategorie analizy, IFiS PAN, Warszawa 2009.

Pasikowski T., Sęk H. (red), Psychologia zdrowia. Teoria, metodologia, empiria, Bogucki Wydawnictwo Naukowe, Poznań 2006.

Piotrowicz M., Cianciara D., Teoria salutogenezy - nowe podejście do zdrowia i choroby, Przegląd Epidemiologiczny, 2011, 65.

Sęk H., Salutogeneza i funkcjonalne wtaściwości poczucia koherencji, [w:] Zdrowie - stres zasoby, red. H. Sęk, T. Pasikowski, Wydawnictwo Fundacji Humaniora, Poznań 2001.

Sęk H., Ścigała I., Stres i radzenie sobie w modelu salutogenetycznym, [w:] Człowiek w sytuacji stresu. Problemy teoretyczne i metodologiczne, red. I. Herszen-Niejodek, Z. Ratajczak, Wydawnictwo Uniwersytetu Śląskiego, Katowice 1996.

Sęk H., Pasikowski T. (red), Zdrowie - stres - zasoby, Wydawnictwo Fundacji Humaniora, Poznań 2001.

Sęk H., Cieślak R. (red), Wsparcie społeczne, stres i zdrowie, Wydawnictwo Naukowe PWN, Warszawa 2004.

Smart R., Peterson C., Super's career stages and the decision to change careers, Journal of Vocational Behavior, 1997, 51. 
Strauser D.R., Lustig D.C., The moderating effect of sense of coherence on work adjustment, Journal of Employment Counseling, 2003, 40.

Super D.E., The psychology of careers, Harper \& Row, New York 1957.

Super D.E., A life-span, life-space approach to career development, [w:] Career choice and development: Applying contemporary theories to practice, red. W.D. Brown, L. Brooks, CA: Jossey-Bass, San Francisco 1990.

Tokarska U., Ksztatcenie kompetencji biograficznej jako forma profilaktyki problemów egzystencjalnych wspótczesnego człowieka, [w:] Poradnictwo. Kolejne przybliżenia, red. M. Piorunek, Wydawnictwo Adam Marszałek, Torun 2011.

Werner I., Poczucie koherencji a praca, [w:] Człowiek w kontekście pracy. Teoria - Empiria Praktyka, red. M. Piorunek, Wydawnictwo Adam Marszałek, Torun 2009.

Worsztynowicz A., Coaching a poczucie koherencji, Forum Oświatowe, 2013, 2(49).

Woynarowska B., Edukacja zdrowotna, Wydawnictwo Naukowe PWN, Warszawa 2016. 